\title{
A GLANCE AT MOLECULAR IDENTIFICATION OF BAMBOO (Poaceae: Bambusoideae)
}

\section{Nabilah Mohamad Khairi ${ }^{1}$, Wilson Thau Lym Yong ${ }^{1 *}$, Julius Kulip², Kenneth Francis Rodrigues ${ }^{1}$}

\author{
'Biotechnology Research Institute, Universiti Malaysia Sabah, Kota Kinabalu, Sabah, Malaysia \\ 2Institute for Tropical Biology and Conservation, Universiti Malaysia Sabah, Kota Kinabalu, Sabah, Malaysia \\ *Corresponding author's email: wilsonyg@ums.edu.my
}

Received date: 27 October 2020 | Accepted date: 16 November 2020

\section{ABSTRACT}

Conservation of plant species plays a vital role in preventing the loss of valuable plant resources. The success of conservation depends on the correct identification and characterization of plant species. Bamboo is one of the most important plants with multiple uses that have contributed to the economy and socio-economy of many people in rural areas. It is under the subfamily of Bambusoideae that includes both woody and herbaceous bamboo. Conventionally, like other plants, bamboo has been classified dependently based on morphological characteristics. However, morphological identification leads to difficulties and misclassification of bamboo species due to their infrequent flowering behaviour and peculiar reproductive biology. Since then, molecular markers have been introduced to overcome the problems associated with bamboo taxonomy and phylogeny. This paper provides an overview of the diverse, predominantly molecular techniques used to assess and determine the genetic diversity of bamboo species.

Keywords: amplified fragment length polymorphism, DNA barcoding, random amplified polymorphic DNA, restriction fragment length polymorphism, sequence characterized amplified region, simple sequence repeat 


\section{INTRODUCTION}

Bamboo is a plant member of the grass family known as Poaceae and constitutes a single subfamily Bambusoideae. The Bambusoideae subfamily consists of both herbaceous or Olyreae tribe and woody bamboos or the Bambuseae tribe (Ram, Thiruvengadam, \& Vinod, 2007). Bamboo comprises approximately 1,290 species, which are naturally distributed worldwide (Hamzah, Hakeem, \& Ibrahim, 2016). There is a rich abundance of bamboo species in the Asia-Pacific and South America (Bystriakova, Kapos, Lysenko, \& Stapleton, 2003; Das, Bhattacharya, Singh, Filgueiras, \& Pal, 2008). The species are mainly classified into three major categories: the pleiotropic woody bamboo, neotropical woody bamboo, and north temperate woody bamboo. The wide variety of species makes bamboo adaptable to many environments and is highly palatable to humans, domestic animals, and wildlife.

Bamboo has emerged as a prospective crop with over 1,500 diversified applications worldwide, ranging from medications to nutrient supplies and from producing toys to aircraft. It is considered the world's best material because of its high tensile strength compared to teak wood and mild steel. It may be a valuable resource for energy because of its fast growth rate ( $5-7$ years to mature) and potential fuel characteristics (Bystriakova et al., 2003). The combination of fast-growing, natural vegetative propagation and their adequacy for making several products makes bamboo ideal for various industrial applications to replace other perennials and woody plants (Bonilla, Guarnetti, Almeida, \& Giannetti, 2010; Hamzah et al., 2016). The traditional phenotypic approach for identifying bamboo species, however, is very complicated, leading to controversy over the classification based on their peculiar vegetative process and flowering characteristics (Isagi et al., 2004; Ramakrishnan et al., 2020; Sharma et al., 2008). These morphological features are often affected by the environment and are complicated, state-specific, and limited in number, contributing to the misclassification of bamboo at the genus and species level (Wu, 1962; Yeasmin, Ali, Gantait, \& Chakraborty, 2015). It is, therefore, essential to have a reliable and precise taxonomic classification and nomenclature system for bamboo to be able to identify and select the best species for growing in the right environment for a purpose that is well suited to it.

\section{TRADITIONAL IDENTIFICATION OF BAMBOO SPECIES}

The identification of bamboo is traditionally based on its morphological characteristics, including rhizomes, buds, leaves, branching patterns, inflorescence, flowers, and fruits. This approach has been problematic because there are limited and peculiar morphological characters in bamboo, particularly its flowers, and the flowering period 
may vary between 15 - 120 years, and some species have never known to flower (Janzen, 1976). Although traditional taxonomy depends heavily on inflorescence and floral morphology, Usui (1957) revealed the importance of branch and bud characters, and McClure (1973) studied the morphology of the rhizome, branching patterns, and culm sheath for bamboo species identification. Soderstrom and Ellis (1988) also considered leaf morphology characters for subfamilial and subtribal level identification, but they failed to apply it at the generic level.

Vegetative characters are often influenced by the environment, making them less constant for systematic purposes (Yeasmin et al., 2015). Various studies have misclassified bamboo species into different taxonomic groups by considering the morphological features that have not been resolved to date. It is not always easy, for example, to define the inflorescence types in bamboos, and in many cases, several conflicting interpretations have been noticed. Chao and Renvoize (1989) recognized the inflorescence of Racemobambos as 'iterauctant', while Dransfield (1992) described it as 'semelauctant'. For its allied genus Neomicrocalamus, related confusion has also been observed (Dransfield, 1992; Stapleton, 1994). Furthermore, basic knowledge of bamboo biology and genetics is still severely lacking. Since morphological identification has not proven successful, there is an urgent need to implement alternative techniques to recognize the taxonomic complexities of bamboo.

\section{DNA FINGERPRINTING IN BAMBOOS}

The use of molecular markers has increased in many branches and subdisciplines of biology as an alternative method for identifying DNA polymorphisms between individuals, studying genetic diversity, and analyzing the genetic distance between species. Determining the appropriate taxonomic level at which it is most informative and correlating it with morphological taxonomic grouping is the major challenge for molecular markers. The application of molecular techniques for studying genetic diversity in bamboo, however, has still been limited to date. The present study aims to review different molecular tools currently used to assess genetic diversity and infer phylogenetic relationships in the bamboos.

Several generations of molecular markers have become increasingly reliable in the past decades. DNA products such as isozymes and secondary compounds, including phenolics, were initially used to explore the phylogenetic relationship between taxa and assess infraspecific polymorphism for species identification (Alam, Sarker, \& Hassan, 1997; Biswas, 1998; Chou \& Hwang, 1985; Pattanaik \& Hall, 2011). Later on, the focus of the research was on variation in the DNA structure, providing two different types of data, namely restriction fragment data (DNA fingerprinting) and gene sequence data (DNA barcoding). In previous phylogenetic analyses of temperate bamboos, especially Phyllostachys and bambusa, molecular markers based 
on restriction fragment length polymorphism (RFLP), random amplified polymorphic DNA (RAPD), amplified fragment length polymorphism (AFLP), and simple sequence repeat (SSR) were used (Table 1; Barkley, Newman, Wang, Hotchkiss, \& Pederson, 2005; Das, Bhattacharya, Basak, \& Pal, 2007; Friar \& Kochert, 1994; Kobayashi, 1997). More recently, DNA sequences have also been used to deduce bamboo phylogenetic relationships, but only limited sequence variations were found in the genes studied (Attigala, Wysocki, Duvall, \& Clark, 2016; Hodkinson, Renvoize, Chonghaile, Stapleton, \& Chase, 2000; Ma, Zhang, Zeng, Guo, \& Li, 2014; Zhang, 2000).

Table 1 Molecular techniques for classification of bamboo species

\begin{tabular}{|c|c|c|}
\hline Techniques ${ }^{*}$ & Species tested & References \\
\hline RFLP & Phyllostachys spp. & Friar and Kochert (1994) \\
\hline RAPD & $\begin{array}{l}\text { Bambusa spp. } \\
\text { Cephalostachyum pergracil } \\
\text { Chimonobambusa spp. } \\
\text { Dendrocalamus spp. } \\
\text { Dinocloa m'Clellandi } \\
\text { Gigantochloa atroviolacea } \\
\text { Neosinocalamus affini } \\
\text { Phyllostachy spp. } \\
\text { Pseudobambusa kurzii } \\
\text { Qiongzhuca tumidinoda } \\
\text { Sasa sp. } \\
\text { Yushania sp. }\end{array}$ & $\begin{array}{l}\text { Biradar et al. (2005) } \\
\text { Das et al. (2007) } \\
\text { Nayak et al. (2003) } \\
\text { Zhang et al. (2011) }\end{array}$ \\
\hline AFLP & $\begin{array}{l}\text { Bambusa spp. } \\
\text { Chimonobambusa marmorea } \\
\text { Dendrocalamus spp. } \\
\text { Gigantochloa spp. } \\
\text { Neomicmlamus andropcgonifolius } \\
\text { Phyllostachys spp. } \\
\text { Shibataea chinensis } \\
\text { Sinobambusa tootsik } \\
\text { Thyrsostachys siamensis }\end{array}$ & $\begin{array}{l}\text { Hodkinson et al. (2000) } \\
\text { Loh et al. (2000) }\end{array}$ \\
\hline SCAR & Bambusa spp. & Das et al. (2005) \\
\hline ISSR & $\begin{array}{l}\text { Bambusa spp. } \\
\text { Dendrocalamus spp. } \\
\text { Melocanna baccifera } \\
\text { Oxytenanthera nigrociliata } \\
\text { Phyllostachys spp. } \\
\text { Pleioblastus spp. } \\
\text { Sasa auricoma } \\
\text { Schizostachyum pergracile } \\
\text { Thyrsostachys oliveri }\end{array}$ & $\begin{array}{l}\text { Lin et al. (2010) } \\
\text { Mukherjee et al. (2010) } \\
\text { Nilkanta et al. (2017) } \\
\text { Tian et al. (2012) } \\
\text { Yang et al. (2012) }\end{array}$ \\
\hline
\end{tabular}




\begin{tabular}{cll}
\hline EST-SSR & Arundinaria spp. & Barkley et al. (2005) \\
& Bambusa spp. & Cai et al. (2019) \\
& Brachystachyum densiflorum & Sharma et al. (2008) \\
Dendrocalamus spp. & \\
& Hibanobambusa tranquillans & \\
Indocalamus spp. & \\
& Melocanna baccifera & \\
& Ochlandra spp. & \\
& Phyllostachys spp. & \\
& Pseudosasa spp. & \\
& Sasa spp. & \\
& Semiarundinaria fastuosa \\
& Shibataea spp. & \\
& Sinobambusa spp. & \\
\hline
\end{tabular}

${ }^{*} \mathrm{RFLP}=$ Restriction fragment length polymorphism; RAPD = Random amplified polymorphism DNA; AFLP = Amplified fragment length polymorphism; SCAR = Sequence characterized amplified region; ISSR = Inter-simple sequence repeat; EST-SSR $=$ Expressed sequence tag-simple sequence repeat

\section{Restriction Fragment Length Polymorphism (RFLP)}

Friar and Kochert (1994) were the first researchers to use RFLP to identify 61 accessions and 20 species of the genus Phyllostachys. RFLP is a polymorphism that results from sequence variation in the genomic DNA recognized by restriction enzymes. The earlier findings of the presence of two distinct sections (Phyllostachys and Heteroclada) in the Phyllostachys species pool were confirmed by RFLP analysis. However, the analysis disagreed with a previous study on putting Phyllostachys nigra under the section of Heteroclada (Wang et al., 1980). Due to the requirements of a large amount of DNA along with the use of radioactive isotopes, the routine use of RFLP in plant genotyping as well as in bamboo has been limited.

\section{Random Amplified Polymorphism DNA (RAPD)}

The RAPD markers are the most straightforward, fastest, and easiest assay to assess the genetic diversity and variation between populations and within them (Kumari \& Pande, 2010). The technique has been successfully employed in determining genetic relationships in various plant species. Nayak, Rout, and Das (2003) assessed the genetic variability using RAPD markers in twelve bamboo species and found a wide range of variability among them with ten random primers. Subsequent cluster analysis showed that the twelve taxa belonging to different bamboo genera formed two major clusters based on similarity indices and three minor clusters from each of the major clusters. In 
a separate study using 80 random primers on the clones of Dendrocalamus strictus and Bambusa bambos, a total of 42 and 32 RAPD markers produced polymorphic patterns in D. strictus and B. bambos, respectively (Biradar, Patil, Kuruvinashetti, Biradar, Patil, \& Yaradoni, 2005). Das et al. (2007) showed a phylogenetic relationship between 15 bamboo species using 32 key morphological descriptors and 120 polymorphic loci of the genomic DNA generated by the RAPD primers. The dendrogram and principal component analysis revealed that their phylogenetic relationships were consistent with the commonly referred bamboo classification system. Still, discriminatory was shown by the cluster pattern generated from the similarity matrix of the key morphological characters. More recently, Zhang, Yang, and Liu (2011) had conducted the RAPD analysis using chloroplast DNA of 22 bamboo species to assess the polymorphisms, similarities, and relationships between them. These studies concluded that molecular evidence based on RAPD markers needs to be accompanied by morphological characteristics to confirm the relationships between taxa.

\section{Amplified Fragment Length Polymorphism (AFLP)}

The AFLP method involving a combination of restriction digestion and PCR amplification was first developed by Vos et al. (1995) and employed by Loh, Kiew, Set, Gan, and Gan (2000) to identify bamboo species and determine their genetic relationships. The study was carried out using a combination of eight primers on 15 bamboo species belonging to four genera in the subtribe Bambusinae. The results showed that the species were divided into different clusters based on 13 unique banding patterns. Molecular markers of AFLP were also used to compare Phyllostachys species (Hodkinson et al., 2000), Bambusa species, and their closely related genera (Loh et al., 2000) for phylogenetic analysis. Compared with RAPD, the use of AFLP and RFLP techniques can produce more polymorphic fragments (bands). However, AFLP is often more expensive, time-consuming, complicated in interpretation, and technically demanding than other alternatives.

\section{Sequence Characterized Amplified Region (SCAR)}

With higher annealing temperatures, SCAR has been developed as an extension of the RAPD analysis with better reproducibility (Paran \& Michelmore, 1993). Later on, two species-specific SCAR markers have been developed for Bambusa balcooa and Bambusa tulda, the two commercially important species for plantations, to aid the paper and pulp industry in the accurate species diagnosis, especially when key morphological features are indistinguishable during the seedling stage (Das, Bhattacharya, \& Pal, 2005). Specifically, the markers were developed from the Bb836 
and Bt609 sequences of the respective species, using primers from both flanking ends of the RAPD primers. They successfully amplified the DNA of individuals representing both $B$. balcooa and B. tulda species. The findings concluded that the two molecular markers were particularly useful for the regulatory establishment of sovereign rights of the B. balcooa and B. tulda germplasms.

\section{Inter-Simple Sequence Repeat (ISSR)}

The molecular markers of ISSR have been used to identify the genetic diversity of many plant species, including bamboos. Due to their more extended primer sequence and higher annealing temperature, ISSR markers are more efficient and reliable than RAPD, resulting in higher stringency (Tikendra, Amom, \& Nongdam, 2019). They have reportedly been used to determine genetic variation and the relationship between various bamboos, including Phyllostachys (Lin et al., 2010), Dendrocalamus (Tian, Yang, Wong, Liu, \& Ruan, 2012; Yang, An, Gu \& Tian, 2012), and Melocanna (Nilkanta, Amom, Tikendra, Rahaman, \& Nongdam, 2017). Lin et al. (2010) crossbred two species of Phyllostachys and successfully identified three hybrids produced by the cross with eight ISSR primers. Furthermore, 25 ISSR markers were used by Mukherjee et al. (2010) to investigate genetic diversity among 22 bamboo taxa, of which 12 resulted in reproducible and scorable bands.

\section{Expressed Sequence Tag-Simple Sequence Repeat (EST-SSR)}

Combining different molecular markers in identifying the genetic diversity among the population species has also been carried out. Barkley et al. (2005) used 25 ESTSSR markers derived from cereal crops including maize, wheat, sorghum, and rice in evaluating the genetic diversity of 92 bamboos classified under 11 genera and 44 species to find out which markers produced well-resolved polymorphic bands. Considering that grass genomes have co-evolved and share large-scale synteny, Sharma et al. (2008) tested 98 rice SSR primers and 20 sugarcane EST-SSR primers on 23 bamboo species. They reported 44 rice and 15 sugarcane SSR primers for transferability to at least one species of bamboo. More recently, Cai et al. (2019) have developed abundant EST-SSR resources from Lei bamboo transcriptome data useful for genetic diversity analysis and molecular verification of bamboo, suggesting that the markers are more effective and reliable than ISSR and other alternatives. 


\section{DNA BARCODING IN BAMBOOS}

As reviewed in this section, DNA barcoding or sequence-based methods for phylogenetic analysis on bamboo and grass have been recorded in several studies to date. DNA barcoding is a way of identifying species based on a short sequence of DNA that varies from species to species but is conserved within species (Hebert, Cywinska, Ball, \& deWaard, 2003). Two plastid gene regions, rbcL and matK, were selected as the core DNA barcodes for all land plants (CBOL Plant Working Group 1 et al., 2009). These plastid regions, which played an essential role in the phylogenetic reconstruction of land plants, were used because of their strong phylogenetic signals in both $r b c L$ and matK (Chase et al., 1993). In previous studies, for both rbcL and matK barcodes, the success rate of generic and species-level identification was around $70 \%$. With a supplementary marker, the identification success improved to $98 \%$.

Besides, Kress, Wurdack, Zimmer, Weigt, \& Janzen (2005) also proposed the nuclear internal transcribed spacer region and plastid trnH-psbA intergenic spacer as potentially usable DNA barcodes for flowering plants. In their study, the two plastid genomes of tobacco and deadly nightshade (belladonna) were compared with closely related species in seven plant families and a group of species collected from a local flora comprising 50 plant families, suggesting that the sequences in this pair of loci have the potential to discriminate between the largest number of plant species for barcoding purposes. Although mitochondrial DNA barcoding is well developed in animals using $\mathrm{CO}$ regions, mitochondrial DNA, however, has low substitution rates and rapidly changing gene content and structure, making it unsuitable for barcoding in plants (Sinha, Kumari, \& Singh, 2012).

\section{Chloroplast DNA Barcode}

The chloroplast genome has long been used to assess the phylogeny of the grass family and resolve systematic problems at the subfamilial and tribal levels (Hilu \& Johnson, 1991). Nadot, Bajon, and Lejeune (1994) used the chloroplast rps 4 gene to construct a phylogenetic tree comprising 28 Poaceae species and resolve the position of Bambusoids with other groups to demonstrate how rice and bamboo were closely related. Meanwhile, the chloroplast $n d h F$ gene was also used to address phylogenetic relationships between 45 grass (i.e. the ingroup) and two outgroup taxa (Clark, Zhang, \& Wendel, 1995). The analysis resulted in the two neotropical herbaceous bamboo tribes, the Streptochaeteae and Anomochloeae, being resolved as the most basal clade within the family, conforming to the primitive features of their unique inflorescences and spikelets. Other researchers also used chloroplast genes, such as matK and $r b c L$, to establish the phylogeny of Poaceae at the subfamilial and tribal levels and study glass systematics and evolution (Cai, Zhang, Zhang, Gao, \& Li, 2012; Hilu, Alice, \& Liang, 1999; Liang \& Hilu, 1996; Yang et al., 2008). Based on a more recent comparative 
analysis using $6.7 \mathrm{~kb}$ of coding and noncoding sequence data and 37 microstructural characters from the chloroplast genome, four main lineages, i.e., temperate woody, paleotropical woody, neotropical woody, and herbaceous bamboos, were recognized in a phylogeny estimation of bamboo tribes and subtribes (Kelchner \& Bamboo Phylogeny Group, 2013).

\section{Nuclear DNA Barcode}

In most cases, nuclear DNA barcodes, mainly ITS regions, were used in conjunction with chloroplast DNA for barcoding plants, including bamboo species. Yang et al. (2008) employed the nuclear ITS and GBSSI gene apart from chloroplast trnL-F DNA sequences to establish a phylogenetic framework of the paleotropical woody bamboos involving 53 species and 17 genera. Using four woody bamboos of the North Temperate Zone as outgroups, the analysis revealed that the ingroup species clustered into three clades: the Bambusinae clade (including Thyrsostachys, Neosinocalamus, Racemobambos, Molecalamus, Dendrocalamopsis, Bambusa, Gigantochloa, Oxytenanthera s. str., Dendrocalamus, Bonia and Neomicrocalamus), the Dinochloa clade, and the Melocanninae clade (including Pseudostachyum, Leptocanna, Cephalostachyum, Melocanna and Schizostachyum s. str.); and further grouped into two monophyletic clades, i.e., the Bambusinae + Dinochloa clade and the Melocanninae clade. Moreover, Cai et al. (2012) suggested that the discriminatory power of the species was substantially enhanced as the nuclear ITS region integrated with a single or combination of plastid markers. Although the ITS alone could identify up to $66.7 \%$ of the examined Bambusoideae taxa, combining ITS and chloroplast $r b c L$ could exhibit the highest species identification power and serve as a potential DNA barcode for temperate woody bamboos.

\section{Multilocus DNA Barcoding}

A combined analysis of multi-gene regions is often useful for improving phylogenetic resolution and support in plant taxonomy. Qiang et al. (2005) compared the genus Arundinaria with other related genera, such as Pleioblastus, Pseudosasa, Oligostachyum, Bashania, and Clavinodum, to determine their phylogenetic relationships by using the nuclear ITS and chloroplast trnL-F intergenic spacer. Sungkaew, Stapleton, Salamin, and Hodkinson (2009) reported phylogenetic groupings within Bambusoideae and resolved several previously unrecognized and poorly supported phylogenetic patterns using five chloroplast DNA regions, trnL intron, trnL-F intergenic spacer, $a t p B-r b c L$ intergenic spacer, rps16 intron, and matK. Cai et al. (2012) analyzed four barcoding markers, namely matK, $r b c L, t r n H-p s b A$, and ITS, in species identification of temperate woody bamboos (Bambusoideae) and recommended $r b c L+$ ITS as a potential barcode region for species discrimination. Furthermore, Sosa, Mejía- 
Saules, Cuéllar, and Vovides (2013) created a DNA barcode library with some leading candidate plastid DNA regions, i.e. matK, $r b c L$, and $p s b l-K$ spacer, as an essential tool for phytosanitary authorities to classify species belonging to groups that command high horticultural trade prices in Mexico. Their study showed that the $p s b /-K$ spacer retrieved more polymorphic sites in bamboos and suggested matK $+p s b l-K$ as the discriminant barcode loci to identify temperate bamboos to at least their generic level. Lately, in the absence of discriminatory features at the juvenile stage, multiple sequence alignment of $p s b A-t r n H$ barcode has been used to certify planting materials, such as micropropagated plantlets, rhizome transplants, and culm cuttings, of the commercial bamboo species (including Bambusa, Dendrocalamus, Melocanna, Oxytenanthera, and Ochlandra) in bamboo nurseries in India (Dev, Sijimol, Prathibha, Sreekumar, \& Muralidharan, 2020).

\section{CONCLUSION}

The bamboo taxonomy is currently in a state of flux, and more phylogenetic studies are required to help resolve the remaining systematic issues. In this paper, we reviewed the availability of numerous molecular-level methods and techniques for achieving bamboo species identification and how the barcoding markers help to provide insights into species-level taxonomy in bamboos. While morphological taxonomy still plays a crucial role in the classification of various bamboo species, molecular markers are undoubtedly valuable tools for addressing phylogenetic questions in the easily confused or cryptic species and can assist traditional approaches in making the identification process more rapid and effective. The availability of the bamboo genome database (http://www.bamboogdb.org/) in the post-genomic era will provide global researchers with a key genomic resource and an extensible analytical platform to better understand the bamboo genome and thus promote future studies based on previous achievements, especially in advanced analysis of phylogenetic and genetic diversity in bamboos.

\section{ACKNOWLEDGEMENTS}

This work was supported by the Universiti Malaysia Sabah under a Niche Research Grant Scheme (DN20091). The authors would like to thank the Biotechnology Research Institute for providing the research platform to conduct the review. 


\section{REFERENCES}

Alam, M. K., Sarker, R. H., \& Hassan, M. A. (1997). Chemotaxonomic studies in peroxidase isozyme of bamboos from Bangladesh. Bangladesh Journal of Botany, 26, 99 - 105.

Attigala, L., Wysocki, W. P., Duvall, M. R., \& Clark, L. G. (2016). Phylogenetic estimation and morphological evolution of Arundinarieae (Bambusoideae: Poaceae) based on plastome phylogenomic analysis. Molecular Phylogenetics and Evolution, 101, 111 121. DOI: https://doi.org/10.1016/j.ympev.2016.05.008

Barkley, N. A., Newman, M. L., Wang, M. L., Hotchkiss, M. W., \& Pederson, G. A. (2005). Assessment of the genetic diversity and phylogenetic relationships of a temperate bamboo collection by using transferred EST-SSR markers. Genome, 48 (4), 731 - 737. DOI: https://doi.org/10.1139/g05-022

Biradar, D. P., Patil, V. C., Kuruvinashetti, M. S., Biradar, M. D., Patil, S. V., \& Yaradoni, S. N. (2005). Characterization of bamboo elite clones from Western ghats of India using RAPD markers. In Proceedings of the role of biotechnology (pp. 155 - 156). Villa Gualino, Turin, Italy.

Biswas, S. (1998). Contribution to the isozyme studies on Indian bamboo, Dendrocalamus strictus (Roxb.) Nees with emphasis on diversity evaluation. Annals of Forestry, 5 (22), $168-172$.

Bonilla, S. H., Guarnetti, R. L., Almeida, C. M. V. B., \& Giannetti, B. F. (2010). Sustainability assessment of a giant bamboo plantation in Brazil: Exploring the influence of labour, time and space. Journal of Cleaner Production, 18 (1), 83 - 91.

Bystriakova, N., Kapos, V., Lysenko, I., \& Stapleton, C. M. A. (2003). Distribution and conservation status of forest bamboo biodiversity in the Asia-Pacific Region. Biodiversity \& Conservation, 12, 1833 - 1841. DOI: https://doi.org/10.1023/A:1024139813651

Cai, K., Zhu, L., Zhang, K., Li, L., Zhao, Z., Zeng, W., \& Lin, X. (2019). Development and characterization of EST-SSR markers from RNA-Seq data in Phyllostachys violascens. Frontiers in Plant Science, 10, 50. DOI: https://doi.org/10.3389/fpls.2019.00050

Cai, Z. M., Zhang, Y. X., Zhang, L. N., Gao, L. M., \& Li, D. Z. (2012). Testing four candidate barcoding markers in temperate woody bamboos (Poaceae: Bambusoideae). Journal of Systematics and Evolution, 50 (6), 527 - 539. DOI: https://doi.org/10.1111/j.17596831.2012.00216.x

CBOL Plant Working Group 1, Hollingsworth, P. M., Forrest, L. L., Spouge, J. L., Hajibabaei, M., Ratnasingham, ... Little, D. P. (2009). A DNA barcode for land plants. Proceedings of the National Academy of Sciences, 106 (31), 12794 - 12797. DOI: https://doi.org/10.1073/ pnas.0905845106

Chao, C. S., \& Renvoize, S. A. (1989). A revision of the species described under Arundinaria (Gramineae) in Southeast Asia and Africa. Kew Bulletin, 44 (2), 349 - 367. DOI: https:// doi.org/10.2307/4110809

Chase, M. W., Soltis, D. E., Olmstead, R. G., Morgan, D., Les, D. H., Mishler, B. D., ... Albert, V. A. (1993). Phylogenetics of seed plants: an analysis of nucleotide sequences from the plastid gene rbcL. Annals of the Missouri Botanical Garden, 80 (3), 528 - 580. DOI: https://doi.org/10.2307/2399846

Chou, C. H., \& Hwang, Y. H. (1985). A biochemical aspect of phylogenetic study of Bambusaceae in Taiwan III. The genera Arthrostylidium, Chimonobambusa and Dendrocalamus. Botanical Bulletin of Academia Sinica, 26 (22), 155 - 170. 
Clark, L. G., Zhang, W., \& Wendel, J. F. (1995). A phylogeny of the grass family (Poaceae) based on $n d h F$ sequence data. Systematic Botany, 20 (4), 436 - 460. DOI: https://doi. org/10.2307/2419803

Das, M., Bhattacharya, S., \& Pal, A. (2005). Generation and characterization of SCARs by cloning and sequencing of RAPD products: a strategy for species-specific marker development in bamboo. Annals of Botany, 95 (5), 835 - 841. DOI: https://doi.org/10.1093/aob/ mci088

Das, M., Bhattacharya, S., Basak, J., \& Pal, A. (2007). Phylogenetic relationships among the bamboo species as revealed by morphological characters and polymorphism analyses. Biologia Plantarum, 51 (4), $667-672$.

Das, M., Bhattacharya, S., Singh, P., Filgueiras, T. S., \& Pal, A. (2008). Bamboo taxonomy and diversity in the era of molecular markers. Advances in Botanical Research, 47, 225 268. DOI: https://doi.org/10.1016/S0065-2296(08)00005-0

Dev, S. A., Sijimol, K., Prathibha, P. S., Sreekumar, V. B., \& Muralidharan, E. M. (2020). DNA barcoding as a valuable molecular tool for the certification of planting materials in bamboo. 3 Biotech, 10, 59. DOI: https://doi.org/10.1007/s13205-019-2018-8

Dransfield, S. (1992). A new species of Racemobambos (Gramineae: Bambusoideae) from Sulawesi with notes on generic delimitation. Kew Bulletin, 47 (4), 707 - 711. DOI: https://doi.org/10.2307/4110711

Friar, E., \& Kochert, G. (1994). A study of genetic variation and evolution of Phyllostachys (Bambusoideae: Poaceae) using nuclear restriction fragment length polymorphisms. Theoretical and Applied Genetics, 89, 265 - 270. DOI: https://doi.org/10.1007/ BF00225152

Hamzah, T. N.T., Hakeem, K. R., \& Ibrahim, F. H. (2016). Proteomics of bamboo, the fast-growing grass. In K. R. Hakeem, H. Tombuloğlu \& G. Tombuloğlu (Eds.), Plant omics: Trends and applications (pp. 327 - 349. Cham: Springer International Publishing.

Hebert, P. D. N., Cywinska, A., Ball, S. L., \& deWaard, J. R. (2003). Biological identifications through DNA barcodes. Proceedings of the Royal Society of London, Series B: Biological Sciences, 270 (1512), 313 - 321. DOI: https://doi.org/10.1098/rspb.2002.2218

Hilu, K. W., \& Johnson, J. L. (1991). Chloroplast DNA reassociation and grass phylogeny. Plant Systematics and Evolution, 176, 21 - 31. DOI: https://doi.org/10.1007/BF00937943

Hilu, K. W., Alice, L. A., \& Liang, H. (1999). Phylogeny of Poaceae inferred from matK sequences. Annals of the Missouri Botanical Garden, 86 (4), 835 - 851. DOI: https://doi. org/10.2307/2666171

Hodkinson, T. R., Renvoize, S. A., Chonghaile, G. N., Stapleton, M. C. A., \& Chase, M. W. (2000). A comparison of ITS nuclear rDNA sequence data and AFLP markers for phylogenetic studies in Phyllostachys (Bambusoideae, Poaceae). Journal of Plant Research, 113, 259 - 269. DOI: https://doi.org/10.1007/PL00013936

Isagi, Y., Shimada, K., Kushima, H., Tanaka, N., Nagao, A., Ishikawa, T., ... Watanabe, S. (2004). Clonal structure and flowering traits of a bamboo [Phyllostachys pubescens (Mazel) Ohwi] stand grown from a simultaneous flowering as revealed by AFLP analysis. Molecular Ecology, 13 (7), 2017 - 2021. DOI: https://doi.org/10.1111/j.1365-294X.2004.02197.x

Janzen, D. H. (1976). Why bamboos wait so long to flower. Annual Review of Ecology and Systematics, 7, 347 - 391. DOI: https://doi.org/10.1146/annurev.es.07.110176.002023

Kelchner, S. A., \& Bamboo Phylogeny Group. (2013). Higher level phylogenetic relationships within the bamboos (Poaceae: Bambusoideae) based on five plastid markers. Molecular Phylogenetics and Evolution, 67 (2), 404 - 413. DOI: https://doi.org/10.1016/j. ympev.2013.02.005 
Kobayashi, M. (1997). Phylogeny of world bamboos analysed by restriction fragment length polymorphisms of chloroplast DNA. In G. P. Chapman (Ed.), The bamboos (pp. 227 234). London: Linnean Society.

Kress, W. J., Wurdack, K. J., Zimmer, E. A., Weigt, L. A., \& Janzen, D. H. (2005). Use of DNA barcodes to identify flowering plants. Proceedings of the National Academy of Sciences, 102 (23), 8369 - 8374. DOI: https://doi.org/10.1073/pnas.0503123102

Kumari, K., \& Pande, A. (2010). Study of genetic diversity in finger millet (Eleusine coracana L. Gaertn) using RAPD markers. African Journal of Biotechnology, 9 (29), 4542 - 4549.

Liang, H., \& Hilu, K. W. (1996). Application of the matK gene sequences to grass systematics. Canadian Journal of Botany, 74 (1), 125 - 134. DOl: https://doi.org/10.1139/b96-017

Lin, X. C., Lou, Y. F., Liu, J., Peng, J. S., Liao, G. L., \& Fang, W. (2010). Crossbreeding of Phyllostachys species (Poaceae) and identification of their hybrids using ISSR markers. Genetics and Molecular Research, 9 (3), 1398 - 1404. DOI: 10.4238/vol9-3gmr855

Loh, J. P., Kiew, R., Set, O., Gan, L. H., \& Gan, Y. Y. (2000). A study of genetic variation and relationships within the bamboo subtribe Bambusinae using amplified fragment length polymorphism. Annals of Botany, 85 (5), 607 - 612. DOI: https://doi.org/10.1006/ anbo.2000.1109

Ma, P. F., Zhang, Y. X., Zeng, C. X., Guo, Z. H., \& Li, D. Z. (2014). Chloroplast phylogenomic analyses resolve deep-level relationships of an intractable bamboo tribe Arundinarieae (Poaceae). Systematic Biology, 63 (6), 933 - 950. DOI: https://doi.org/10.1093/sysbio/ syu054

McClure, F. A. (1973). Genera of bamboos native to the new world (Gramineae: Bambusoideae) (No. 9). T. R. Soderstrom (Ed.). Washington: Smithsonian Institution Press.

Mukherjee, A. K., Ratha, S., Dhar, S., Debata, A. K., Acharya, P. K., Mandal, S., ... Mahapatra, A. K. (2010). Genetic relationships among 22 taxa of bamboo revealed by ISSR and ESTbased random primers. Biochemical Genetics, 48, 1015 - 1025. DOI: 10.1007/s10528010-9390-8

Nadot, S., Bajon, R., \& Lejeune, B. (1994). The chloroplast gene rps4 as a tool for the study of Poaceae phylogeny. Plant Systematics and Evolution, 191, 27 - 38. DOI: https://doi. org/10.1007/BF00985340

Nayak, S., Rout, G. R., \& Das, P. (2003). Evaluation of the genetic variability in bamboo using RAPD markers. Plant Soil and Environment, 49 (10), 24 - 28.

Nilkanta, H., Amom, T., Tikendra, L., Rahaman, H., \& Nongdam, P. (2017). ISSR marker based population genetic study of Melocanna baccifera (Roxb.) Kurz: a commercially important bamboo of Manipur, North-East India. Scientifica, 2017, 3757238. DOI: https://doi.org/10.1155/2017/3757238

Paran, I., \& Michelmore, R. W. (1993). Development of reliable PCR-based markers linked to downy mildew resistance genes in lettuce. Theoretical and Applied Genetics, 85, $985-$ 993. DOI: https://doi.org/10.1007/BF00215038

Pattanaik, S., \& Hall, J. B. (2011). Molecular evidence for polyphyly in the woody bamboo genus Dendrocalamus (subtribe Bambusinae). Plant Systematics and Evolution, 291, 59 - 67. DOI: https://doi.org/10.1007/s00606-010-0380-4

Qiang, Z., Yu-long, D., Chen, X., Hui-yu, Z., Ming-ren, H., \& Ming-xiu, W. (2005). A preliminary analysis of phylogenetic relationships of Arundinaria and related genera based on nucleotide sequences of nrDNA (ITS region) and cpDNA (trnL-F intergenic spacer). Journal of Forestry Research, 16, 5 - 8. DOI: https://doi.org/10.1007/BF02856844 
Ram, S. G., Thiruvengadam, V., \& Vinod, K. K. (2007). Genetic diversity among cultivars, landraces and wild relatives of rice as revealed by microsatellite markers. Journal of Applied Genetics, 48, 337 - 345.

Ramakrishnan, M., Yrjälä, K., Vinod, K. K., Sharma, A., Cho, J., Sateesh, V., \& Zhou, M. (2020). Genetics and genomics of moso bamboo (Phyllostachys edulis): Current status, future challenges, and biotechnological opportunities toward a sustainable bamboo industry. Food and Energy Security, 9 (4), e229. DOI: https://doi.org/10.1002/fes3.229

Sharma, R. K., Gupta, P., Sharma, V., Sood, A., Mohapatra, T., \& Ahuja, T. S. (2008). Evaluation of rice and sugarcane SSR markers for phylogenetic and genetic diversity analyses in bamboo. Genome, 51 (2), 91 - 103. DOI: https://doi.org/10.1139/G07-101

Sinha, A., Kumari, K., \& Singh, S. (2012). DNA barcoding for species identification in bamboos. Forestry Bulletin, 12 (2), $73-77$.

Soderstrom, T. R., \& Ellis, R. P. (1988). The woody bamboos (Poaceae: Bambuseae) of Sri Lanka: A morphological-anatomical study (Vol. 72). Washington: Smithsonian Institution Press.

Sosa, V., Mejía-Saules, T., Cuéllar, M. A., \& Vovides, A. P. (2013). DNA barcoding in endangered Mesoamerican groups of plants. The Botanical Review, 79, 469 - 482. DOI: 10.1007/ s12229-013-9129-4

Stapleton, C. M. A. (1994). The bamboos of Nepal and Bhutan. Part III: Drepanostachyum, Himalayacalamus, Ampelocalamus, Neomicrocalamus and Chimonobambusa (Gramineae: Poaceae, Bambusoideae). Edinburgh Journal of Botany, 51 (3), 301 - 330.

Sungkaew, S., Stapleton, C. M. A., Salamin, N., \& Hodkinson, T. R. (2009). Non-monophyly of the woody bamboos (Bambuseae; Poaceae): a multi-gene region phylogenetic analysis of Bambusoideae s.s. Journal of Plant Research, 122, 95. DOI: https://doi.org/10.1007/ s10265-008-0192-6

Tian, B., Yang, H. Q., Wong, K. M., Liu, A. Z., \& Ruan, Z. Y. (2012). ISSR analysis shows low genetic diversity versus high genetic differentiation for giant bamboo, Dendrocalamus giganteus (Poaceae: Bambusoideae), in China populations. Genetic Resources and Crop Evolution, 59, 901 - 908. DOI: https://doi.org/10.1007/s10722-011-9732-3

Tikendra, L., Amom, T., \& Nongdam, P. (2019). Molecular genetic homogeneity assessment of micropropagated Dendrobium moschatum Sw. - A rare medicinal orchid, using RAPD and ISSR markers. Plant Gene, 19, 100196. DOI: https://doi.org/10.1016/j. plgene.2019.100196

Usui, H. (1957). Morphological studies on the prophyll of Japanese bamboos. Botanical Magazine Tokyo, 70, 223 - 227.

Vos, P., Hogers, R., Bleeker, M., Reijans, M., van de Lee, T., Hornes, M., ... Zabeau, M.(1995). AFLP: A new technique for DNA fingerprinting. Nucleic Acids Research, 23 (21), 4407 - 4414. DOI: https://doi.org/10.1093/nar/23.21.4407

Wang, C. P., Yu, T. H., Ye, K. H., Chu, C. T., Chao, C. S., Chen, S. Y., ... Chao, H. J. (1980). A taxonomical study of Phyllostachys, China (cont.). Acta Phytotaxonomica Sinica, 18 (1), 168 - 193.

Wu, M. C. Y. (1962). The classification of Bambuseae based on leaf anatomy. Botanical Bulletin of Academia Sinica, 3 (11), 83 - 107.

Yang, H. Q., An, M. Y., Gu, Z. J., \& Tian, B. (2012). Genetic diversity and differentiation of Dendrocalamus membranaceus (Poaceae: Bambusoideae), a declining bamboo species in Yunnan, China, as based on inter-simple sequence repeat (ISSR) analysis. International Journal of Molecular Sciences, 13 (4), 4446 - 4457. https://doi.org/10.3390/ ijms13044446 
Yang, H. Q., Yang, J. B., Peng, Z. H., Gao, J., Yang, Y. M., Peng, S., \& Li, Z. (2008). A molecular phylogenetic and fruit evolutionary analysis of the major groups of the paleotropical woody bamboos (Gramineae: Bambusoideae) based on nuclear ITS, GBSSI gene and plastid trnL-F DNA sequences. Molecular Phylogenetics and Evolution, 48 (3), 809 - 824. DOI: https://doi.org/10.1016/j.ympev.2008.06.001

Yeasmin, L., Ali, M. N., Gantait, S., \& Chakraborty, S. (2015). Bamboo: an overview on its genetic diversity and characterization. 3 Biotech, 5, 1 - 11. DOI: https://doi.org/10.1007/ s13205-014-0201-5

Zhang, H. Y., Yang, Y. M., \& Liu, X. Z. (2011). Bamboo species relations revealed by random amplified polymorphism chloroplast DNA. African Journal of Agricultural Research, 6 (5), 1241 - 1245. DOI: https://doi.org/10.5897/AJAR10.794

Zhang, W. (2000). Phylogeny of the grass family (Poaceae) from rp/16 intron sequence data. Molecular Phylogenetics and Evolution, 15 (1), 135 - 146. DOI: https://doi.org/10.1006/ mpev.1999.0729 
